\title{
Creativity and Organizational Spaces Between Learning and Efficiency
}

\author{
Daniela Dimitrova Popova, Zdravko Dimitrov Slavov \\ Department of International Economics and Politics, Varna Free University “Chernorizets Hrabar”, Varna, Bulgaria
}

Email address:

popovadaniela@hotmail.com (D. D. Popova),slavovibz@yahoo.com (Z. D. Slavov)

To cite this article:

Daniela Dimitrova Popova, Zdravko Dimitrov Slavov. Creativity and Organizational Spaces Between Learning and Efficiency. American Journal of Applied Psychology. Vol. 6, No. 5, 2017, pp. 132-137. doi: 10.11648/j.ajap.20170605.18

Received: June 15, 2017; Accepted: July 7, 2017; Published: October 24, 2017

\begin{abstract}
The aim of the paper is to present an approach toward creativity and learning in business context in two lines. The first is referred to the processes of creativity as organizational assets and capital. The second line involves a focus on actual learnings settings where the evaluation of results produces new ideas, approaches, contexts, vision, efficiency, organizational needs and goals. This paper discusses Amy Edmondson's scientific approach to execution-as-learning and the research on execution-as-efficiency (2008). The results include the assumption that a larger independence in assertions from each group (on execution-as-learning and execution-as-efficiency) is needed in an organizational context.
\end{abstract}

Keywords: Creativity, Organization, Efficiency, Learning, Analysis

\section{Introduction}

While the study of creativity is a central topic and issues of it have conceived in psychological research and theory in recent decades, it remains relatively unexamined in the field of economics. The importance of creativity in an organizational context is due to:

First, specificity of the learning environment and outcomes;

Second, psychological attitudes towards novelty and imagination in processes' implementations by using marketing tools, production technologies, relationships' entrepreneurial patterns and cultural mapping as a diversity resource for innovations;

Third, microfoundations of creativity (Erik E. Guzik \& Kathy Goff, 2015) [1], that is, understandings of creativity that connect to the central building blocks of modern microeconomics - specifically, the individual agents of production (the firm) and consumption (the consumer);

Fourth, necessity for linkage of organizational execution between learning and efficiency, etc.

\section{Creativity in the Organizational Execution and Learning Settings}

The rise in creativity research often is associated with J. P.
Guilford's 1950 presidential address to the American Psychological Association. "Although there were studies of creativity prior to the $1950 \mathrm{~s}$, Guilford is credited with persuading psychologists of the need and possibility for scientific studies of creativity (Runco, 2004). In particular, Guilford (1950) challenged psychologists to focus on the discovery and cultivation of creativity in schoolchildren. Guilford's focus on the creativity of children in schools was the upshot of his recognition of the relationship between creativity and learning; many classic learning theorists have shared this view, including Piaget and Vygotsky (Sawyer et al., 2003)" [2].

The concept of organizational learning has developed and there exist different meanings and ideas in the literature about it. Chris Argyris and Donald Schön (1978) defined it as "the detection and correction of error" and have drawn three types of organizational learning (single-loop learning; double-loop learning and deutero-learning). Daft \& Weick (1966) consider that organizational learning is knowledge about the interrelationships between the organization's action and the environment. Lee et al. (1992) viewed the organizational learning process as "a cyclical one in which individual's actions lead to organizational interactions with the environment. Environmental responses are interpreted by individuals who learn by updating their beliefs about causeeffect relationships." Fiol \& Lyles (1985) describe organizational learning as "the process of improving actions 
through better knowledge and understanding." [3]

The relationship between organizational learning and creativity is a key focus of the organizational creativity concept referred to:

First, the participants of the creative processes, so called creators and creative thinkers;

Second, the understanding of the everyday nature of creative thinking (Richards, Kinney, Benet, \& Merzel, 1988; Runco \& Bahleda, 1986);

Third, the role that creativity plays in the development of new and personally meaningful knowledge (Beghetto \& Plucker, 2006);

Fourth, the cultural mosaic of learning styles and execution as efficiency obligations and schemes in building the microfoundations of creativity, etc.

Erik E. Guzik \& Kathy Goff (2015) argue that "the dominant definition today offered by psychology to understand what creativity is - an ability to generate novel output that has value (Sarkar \& Chakrabarti, 2011) - includes as its underlying basis, two concepts (novel output and value) that are central to the science of modern microeconomics". Conceptualizations of creativity depend on the role of microeconomics as a potential theoretical tool for: (1) developing a more comprehensive understanding of creativity at the level of the individual creator in an organizational context and efficiency as execution; and (2) better understanding the vital role played by individual consumer in securing creative activity and value through learning and producing knowledge about specific needs and behavior motivators.

Creative artifacts nowadays distinguish creative thinkers' schemes that describe technologies of management and organization in the learning settings of a company. More standard psychometric approaches that seek to measure individual creativity are used to quantify a person's individual creativity (or psychological capacity for creative thought). "For example, the Torrance Test of creativity is one of the more common creativity tests, and is designed as a psychological measurement of an individual's divergent thinking" [4]. The approach of Mishra et al. (2013), has differences in its purpose, the focus is on the products of creative activity, i.e. they try to evaluate the end products of creative process. "These "end products" may include physical objects, concepts and ideas, or artifacts such as poems and theories. Our focus on artifacts highlights the philosophical proposition that it is what we do that matters (not what a test thinks we are). Our emphasis on the end products of the creative process is driven by two reasons." [4] Our approach toward creativity and learning in business context develops Mishra (et al.)'s standpoint on end products in two lines. The first is referred to the processes of creativity as organizational assets that are often invisible to the outsiders. The results at the end of the process, is what the creative organization implements. The second line involves a focus on actual learnings settings where the evaluation of results produces new ideas, approaches, contexts, vision, efficiency, organizational needs and goals.

Some approaches towards organizational spaces in the process of execution as efficiency and/or learning could draw organizational assets and dimensions in some directions as:

(1) Organizing work for high performance [5];

(2) Creating synergy among cultural diversity and employees by coordination;

(3) Developing a global work context to define activities that maximize efficiency;

(4) Designing the structural variations of company's projects according to procedures and standards;

(5) Explicating levels of job enlargement, duties, responsibilities and the context of hierarchical relationships;

(6) Creating a platform for self-management and improvement of the organizational context of self-managed teams;

(7) Engaging in self-efficacy and perceptions of the social context (Borgogni et al., 2016) [6];

(8) Placing the strategic discourse in selection and promotion of effective global leaders at all organizational levels (Butler, Zander, Mockaitis, \& Sutton, 2012; Tung \& Varma, 2008, et al. [7]);

(9) Searching for global competence - managerial, cultural, and operational [8];

(10) Recognizing the benefits and effects of the teams' performance;

(11) Representing successful perspectives for organizational spaces in multicultural settings;

(12) Developing of leaders-teams relationships;

(13) Self - managing through feedback analysis (Drucker, 1999) [9];

(14) Increasing coordination and collaboration by implementation of promise-based management (Sull, 2007) [10];

(15) Achieving a sense of community within personal networks;

(16) Coaching the employees on their attitudes and roles in the process;

(17) Sharing the expectations, solutions, information and behaviors' parameters;

(18) Giving a feedback, personal encouragement and progressive approaches toward uncertainty about clear hierarchy;

(19) Providing a focus that defines responsibilities, participation in business processes, specific actions;

(20) Securing supportive and feedback relationships in order to reduce organizational stress;

(21) Rethinking the strategy in the context of business environment;

(22) Implementing the Japanese concept of ba (Nonaka \& Konno, 1998) [11];

(23) Achieving the ability to promote or institute spontaneous knowledge-sharing in occupational communities, to embed the knowledge exchange practices into innovation processes (The Hau-Ba Model - from the concept of ba to the community-order perspective, Ahmed Bounfour \& Gwénaëlle Grefe, (2014) [11];

(24) Applying the whole company's energies to generate ideas about leadership efficiency; management innovative 
approaches toward productivity, creative usage of time and organizational spaces, etc.

\section{Methodology, Findings and Discussion}

The methodology of the paper includes the identification and exploring of Amy Edmondson's [12] scientific approach to execution-as-learning (2008) and the research on execution-as-efficiency. It is supposed that the assertions in the groups "execution-as-efficiency" and "execution-aslearning" would outline the verification of valid data and using this approach the aim is to be investigated throughout questionnaires the opinions of 25 representatives from the tourism industry of the Republic of Bulgaria.

The variables of the first group assertions have individual codes: E01, E02, E03, E04, E05, E06 and E07. Actually these are relevant assertions referred to efficiency and the data includes the values of the variables.

The variables of the second group assertions referred to learning are marked as L01, L02, L03, L04, L05, L06 and L07.

It becomes noticeable that there is missing data in some of the polls. There are eighteen questionnaires that are completed in full and in the other seven there is missing data. In the processing only available data is taken into account in the calculations.

The number of men is very small compared with the number of women and that does not make sense to do a statistical analysis by gender.

Table 1. Leaders provide answers (E01).

\begin{tabular}{llllll}
\hline & Frequency & Percent & $\begin{array}{l}\text { Valid } \\
\text { Percent }\end{array}$ & $\begin{array}{l}\text { Cumulative } \\
\text { Percent }\end{array}$ \\
\hline Valid & 0 & 10 & 40,0 & 40,0 & 40,0 \\
& 1 & 15 & 60,0 & 60,0 & 100,0 \\
& Total & 25 & 100,0 & 100,0 & \\
\hline
\end{tabular}

Table 2. Employees follow directions (E02).

\begin{tabular}{llllll}
\hline & Frequency & Percent & $\begin{array}{l}\text { Valid } \\
\text { Percent }\end{array}$ & $\begin{array}{l}\text { Cumulative } \\
\text { Percent }\end{array}$ \\
\hline Valid & 0 & 2 & 8,0 & 8,0 & 8,0 \\
& 1 & 23 & 92,0 & 92,0 & 100,0 \\
& Total & 25 & 100,0 & 100,0 & \\
\hline
\end{tabular}

Table 3. Optimal work processes are designed and set up in advance (E03).

\begin{tabular}{llllll}
\hline & Frequency & Percent & $\begin{array}{l}\text { Valid } \\
\text { Percent }\end{array}$ & $\begin{array}{l}\text { Cumulative } \\
\text { Percent }\end{array}$ \\
\hline Valid & 0 & 7 & 28,0 & 28,0 & 28,0 \\
& 1 & 18 & 72,0 & 72,0 & 100,0 \\
& Total & 25 & 100,0 & 100,0 & \\
\hline
\end{tabular}

Table 4. New work processes are developed infrequently; implementing change is a huge undertaking (E04).

\begin{tabular}{llllll}
\hline & Frequency & Percent & $\begin{array}{l}\text { Valid } \\
\text { Percent }\end{array}$ & $\begin{array}{l}\text { Cumulative } \\
\text { Percent }\end{array}$ \\
\hline Valid & 0 & 13 & 52,0 & 56,5 & 56,5 \\
& 1 & 10 & 40,0 & 43,5 & 100,0 \\
& Total & 23 & 92,0 & 100,0 & \\
Missing & System & 2 & 8,0 & & \\
Total & & 25 & 100,0 & & \\
\hline
\end{tabular}

Table 5. Feedback is typically one-way (from boss to employee) and corrective ("You're not doing it right.") (E05).

\begin{tabular}{llllll}
\hline & & Frequency & Percent & $\begin{array}{l}\text { Valid } \\
\text { Percent }\end{array}$ & $\begin{array}{l}\text { Cumulative } \\
\text { Percent }\end{array}$ \\
\hline Valid & 0 & 13 & 52,0 & 54,2 & 54,2 \\
& 1 & 11 & 44,0 & 45,8 & 100,0 \\
& Total & 24 & 96,0 & 100,0 & \\
Missing & System & 1 & 4,0 & & \\
Total & & 25 & 100,0 & & \\
\hline
\end{tabular}

Table 6. Problem solving is rarely required; judgment is not expected; employees ask managers when they're unsure (E06).

\begin{tabular}{llllll}
\hline & Frequency & Percent & $\begin{array}{l}\text { Valid } \\
\text { Percent }\end{array}$ & $\begin{array}{l}\text { Cumulative } \\
\text { Percent }\end{array}$ \\
\hline Valid & 0 & 9 & 36,0 & 40,9 & 40,9 \\
& 1 & 13 & 52,0 & 59,1 & 100,0 \\
& Total & 22 & 88,0 & 100,0 & \\
Missing & System & 3 & 12,0 & & \\
Total & & 25 & 100,0 & & \\
\hline
\end{tabular}

Table 7. Fear (of the boss or of consequences) is often part of the work environment and generally does not appreciably harm the quality of execution; it may even motivate effort and attentiveness in those facing an otherwise dull task (E07).

\begin{tabular}{llllll}
\hline & Frequency & Percent & $\begin{array}{l}\text { Valid } \\
\text { Percent }\end{array}$ & $\begin{array}{l}\text { Cumulative } \\
\text { Percent }\end{array}$ \\
\hline Valid & 0 & 8 & 32,0 & 36,4 & 36,4 \\
& 1 & 14 & 56,0 & 63,6 & 100,0 \\
& Total & 22 & 88,0 & 100,0 & \\
Missing & System & 3 & 12,0 & & \\
Total & & 25 & 100,0 & & \\
\hline
\end{tabular}

It could be remarked that the assertions in the first group comprise mostly "yes" choices. Exceptions are E04 and E05.

Table 8. Leaders set direction and articulate the mission (LO1).

\begin{tabular}{llllll}
\hline & Frequency & Percent & $\begin{array}{l}\text { Valid } \\
\text { Percent }\end{array}$ & $\begin{array}{l}\text { Cumulative } \\
\text { Percent }\end{array}$ \\
\hline Valid & 0 & 7 & 28,0 & 28,0 & 28,0 \\
& 1 & 18 & 72,0 & 72,0 & 100,0 \\
& Total & 25 & 100,0 & 100,0 & \\
\hline
\end{tabular}

Table 9. Employees (usually in teams) discover answers (L02).

\begin{tabular}{llllll}
\hline & Frequency & Percent & $\begin{array}{l}\text { Valid } \\
\text { Percent }\end{array}$ & $\begin{array}{l}\text { Cumulative } \\
\text { Percent }\end{array}$ \\
\hline Valid & 0 & 5 & 20,0 & 20,8 & 20,8 \\
& 1 & 19 & 76,0 & 79,2 & 100,0 \\
& Total & 24 & 96,0 & 100,0 & \\
Missing & System & 1 & 4,0 & & \\
Total & & 25 & 100,0 & & \\
\hline
\end{tabular}

Table 10. Tentative work processes are set up as a starting point (LO3).

\begin{tabular}{llllll}
\hline & Frequency & Percent & $\begin{array}{l}\text { Valid } \\
\text { Percent }\end{array}$ & $\begin{array}{l}\text { Cumulative } \\
\text { Percent }\end{array}$ \\
\hline Valid & 0 & 16 & 64,0 & 69,6 & 69,6 \\
& 1 & 7 & 28,0 & 30,4 & 100,0 \\
& Total & 23 & 92,0 & 100,0 & \\
Missing & System & 2 & 8,0 & & \\
Total & & 25 & 100,0 & & \\
\hline
\end{tabular}


Table 11. Work processes keep developing; small changes-experiments and improvements - are a way of life (LO4).

\begin{tabular}{llllll}
\hline & & Frequency & Percent & $\begin{array}{l}\text { Valid } \\
\text { Percent }\end{array}$ & $\begin{array}{l}\text { Cumulative } \\
\text { Percent }\end{array}$ \\
\hline Valid & 0 & 7 & 28,0 & 31,8 & 31,8 \\
& 1 & 15 & 60,0 & 68,2 & 100,0 \\
& Total & 22 & 88,0 & 100,0 & \\
Missing & System & 3 & 12,0 & & \\
Total & & 25 & 100,0 & & \\
\hline
\end{tabular}

Table 12. Feedback is always two-way: The boss gives feedback in the form of coaching and advice; team members give feedback about what they're learning from doing the (ever-changing) work (LO5).

\begin{tabular}{llllll}
\hline & & Frequency & Percent & $\begin{array}{l}\text { Valid } \\
\text { Percent }\end{array}$ & $\begin{array}{l}\text { Cumulative } \\
\text { Percent }\end{array}$ \\
\hline Valid & 0 & 6 & 24,0 & 25,0 & 25,0 \\
& 1 & 18 & 72,0 & 75,0 & 100,0 \\
& Total & 24 & 96,0 & 100,0 & \\
Missing & System & 1 & 4,0 & & \\
Total & & 25 & 100,0 & & \\
\hline
\end{tabular}

Table 13. Problem solving is constantly needed, so valuable information is provided to guide employees' judgment (L06).

\begin{tabular}{llllll}
\hline & & Frequency & Percent & $\begin{array}{l}\text { Valid } \\
\text { Percent }\end{array}$ & $\begin{array}{l}\text { Cumulative } \\
\text { Percent }\end{array}$ \\
\hline Valid & 0 & 4 & 16,0 & 16,7 & 16,7 \\
& 1 & 20 & 80,0 & 83,3 & 100,0 \\
& Total & 24 & 96,0 & 100,0 & \\
Missing & System & 1 & 4,0 & & \\
Total & & 25 & 100,0 & & \\
\hline
\end{tabular}

Table 14. Fear cripples the learning process: It inhibits experimentation, lowers awareness of options, and discourages people from sharing and analyzing insights, questions, and problems (L07).

\begin{tabular}{llllll}
\hline & & Frequency & Percent & $\begin{array}{l}\text { Valid } \\
\text { Percent }\end{array}$ & $\begin{array}{l}\text { Cumulative } \\
\text { Percent }\end{array}$ \\
\hline Valid & 0 & 5 & 20,0 & 20,8 & 20,8 \\
& 1 & 19 & 76,0 & 79,2 & 100,0 \\
& Total & 24 & 96,0 & 100,0 & \\
Missing & System & 1 & 4,0 & & \\
Total & & 25 & 100,0 & & \\
\hline
\end{tabular}

It could be concluded that the assertions in the second group also comprise mostly "yes" choices. The only exception is L03.

The correlation analysis below adds other perspectives to be observed (table 15, table 16, table 17).

Table 15. Correlation analysis in the first group.

\begin{tabular}{|c|c|c|c|c|c|c|c|c|}
\hline & & E01 & E02 & E03 & E04 & E05 & E06 & E07 \\
\hline E01 & Pearson Correlation & 1 & ,361 &, 218 &,- 280 &,- 324 &,- 203 &,- 121 \\
\hline E02 & Pearson Correlation & ,361 & 1 &, 144 &,- 352 &,- 328 &, 058 &,- 239 \\
\hline E03 & Pearson Correlation & ,218 & ,144 & 1 & ,008 &,- 146 &, 027 &,- 111 \\
\hline E04 & Pearson Correlation &,- 280 &,- 352 &, 008 & 1 & ,469 & ,302 & ,612 \\
\hline E05 & Pearson Correlation &,- 324 &,- 328 &,- 146 & ,469 & 1 & ,138 & ,234 \\
\hline E06 & Pearson Correlation &,- 203 &, 058 &, 027 & ,302 &, 138 & 1 &, 524 \\
\hline E07 & Pearson Correlation &,- 121 &,- 239 &,- 111 & ,612 & ,234 &, 524 & 1 \\
\hline
\end{tabular}

Conclusion: It is noteworthy that a correlation relationship between two variables in this group is not high, but both positive and negative. Therefore, in principle position the assertions in this group are highly interconnected.

The highest correlation $(>0.5)$ is between the variables E04 and E07 and between the variables E06 and E07, respectively equal to 0.612 and 0.524 . Only positive correlations are observed.

The smallest correlation $(<0.1)$ : between variables E02 and E06, between variables E03 and E04 and between variables E03 and E06, respectively equal to 0.058, 0.008 and 0.027 . Only positive correlations are observed.

Table 16. Correlation analysis in the second group.

\begin{tabular}{|c|c|c|c|c|c|c|c|c|}
\hline & & L01 & L02 & $\mathbf{L 0 3}$ & L04 & L05 & L06 & $\mathbf{L 0 7}$ \\
\hline L01 & Pearson Correlation & 1 & ,348 & , 178 & ,020 &, 476 & ,205 &,- 103 \\
\hline L02 & Pearson Correlation & ,348 & 1 & ,370 & ,636 & ,407 &, 314 &,- 022 \\
\hline L03 & Pearson Correlation &, 178 &, 370 & 1 & ,224 &, 418 & ,069 &, 069 \\
\hline L05 & Pearson Correlation & ,476 & ,407 & ,418 & ,239 & 1 & ,258 &,- 059 \\
\hline L06 & Pearson Correlation & ,205 &, 314 & ,069 & ,184 &, 258 & 1 & ,596 \\
\hline L07 & Pearson Correlation &,- 103 &,- 022 & ,069 & ,095 &,- 059 &, 596 & 1 \\
\hline
\end{tabular}

Conclusion: It is noteworthy that a correlation relationship between any two variables in this group is not high. It is both positive and negative. Therefore, principle position the assertions in this group are highly interconnected.

The highest correlation $(>0.5)$ is between the variables L02 and L04, between the variables L06 and L07, respectively equal to 0.636 and 0.596 . Only positive correlations are observed.

The smallest correlation $(<0.1$ in absolute value $)$ is between variables L01 and L04, between variables L02 and L07, between variables L03 and L06, between variables L03 and L07, between variables L04 and L07 and between variables L05 and L07, respectively equal to $0.020,-0.022,0.069,0.069,0.095$ and -0.059 . There are both positive and negative correlations. 
Table 17. Correlation analysis between the variables in the two groups (one variable per group).

\begin{tabular}{|c|c|c|c|c|c|c|c|c|c|c|c|c|c|c|c|}
\hline & L01 & $\mathrm{LO2}$ & $L 03$ & L04 & $L 05$ & $L 06$ & L07 & & $L 01$ & $\mathrm{LO2}$ & $L 03$ & L04 & $L 05$ & $L 06$ & L07 \\
\hline$E 01$ & ,764 & ,399 &,- 051 & ,027 & 293 & ,076 &,- 225 & $E 01$ & ,764 & & & & & & \\
\hline E02 & ,473 & ,217 & ,204 & ,123 & ,522 &,- 135 &,- 155 & E02 & & ,217 & & & & & \\
\hline E03 & ,206 & ,122 &,- 384 & ,162 & ,265 & ,205 & ,122 & E03 & & &,- 384 & & & & \\
\hline E04 &,- 388 &,- 280 &,- 232 &,- 135 &,- 158 & ,363 & ,495 & E04 & & & &,- 135 & & & \\
\hline E05 &,- 435 &,- 388 &,- 255 &,- 488 &,- 422 &,- 020 & ,294 & E05 & & & & &,- 422 & & \\
\hline E06 &,- 171 & 022 &, 154 &, 000 & ,113 & 087 & ,087 & E06 & & & & & & 087 & \\
\hline E07 &,- 111 &,- 158 & ,089 &,- 139 &,- 039 & ,134 & ,134 & E07 & & & & & & & ,134 \\
\hline
\end{tabular}

Both positive and negative correlations are observed. It is worth noting the presence of a large number of weak relationships.

Weakest relationships: between E01 and L03 (- 0,051), E01 and L04 (0,027), E01 and L06 (0,076), E05 and L06 (0,020), E06 and L02 (0,022), E06 and L04 (0), E06 and L06 $(0,087)$, E06 and L07 (0,087), E07 and L03 (0,089), E07 and L05 (- 0,039). There are both positive and negative. The strongest relationships are between E01 and L01 $(0,764)$, E02 and L05 (0,522). They are only positive.

The correlation between the variables marks some directions of the analysis. Looking at the contents of the relevant assertions, it could be deduced the hypothesis that given answers should have a strong correlation, and actual results show otherwise. Both positive and negative correlation is observed, also both strong and weak correlation, but there is a very weak correlation (it was a characteristic of relations in each group). Positive correlations are observed between first, second, sixth and seventh assertions, and negative correlations are between the third, fourth and fifth ones. It is noteworthy the strong correlation between the first assertions that is equal to 0.764 .

A new variable $\mathrm{E}$ is introduced, which includes the number of positive responses in the first group of each respondent. The results are given in the table 18 below:

Table 18. Variables E\&L E L.

\begin{tabular}{|c|c|c|c|c|c|c|c|c|c|}
\hline & & Frequency & Percent & Valid Percent & & & Frequency & Percent & Valid Percent \\
\hline \multirow[t]{7}{*}{ Valid } & 1 & 1 & 4,0 & 5,0 & Valid & 0 & 1 & 4,0 & 5,0 \\
\hline & 2 & 1 & 4,0 & 5,0 & & 2 & 2 & 8,0 & 10,0 \\
\hline & 3 & 4 & 16,0 & 20,0 & & 4 & 6 & 24,0 & 30,0 \\
\hline & 4 & 5 & 20,0 & 25,0 & & 5 & 3 & 12,0 & 15,0 \\
\hline & 5 & 4 & 16,0 & 20,0 & & 6 & 4 & 16,0 & 20,0 \\
\hline & 6 & 4 & 16,0 & 20,0 & & 7 & 4 & 16,0 & 20,0 \\
\hline & 7 & 1 & 4,0 & 5,0 & & Total & 20 & 80,0 & 100,0 \\
\hline Missing & System & 5 & 20,0 & & Total & & 25 & 100,0 & \\
\hline Total & & 25 & 100,0 & & & & & & \\
\hline
\end{tabular}

The most often used responses are positive (four "yes" choices). It is used a new variable $\mathrm{L}$, which is the number of positive responses in the second group of each respondent. The results are given in the table 18 above. Again most often given are the positive responses (four "yes" choices). A new variable EL is introduced, which is the number of total positive responses for both groups of each respondent. The results are given in the table 19 below:

Table 19. Variable EL EL.

\begin{tabular}{llllll}
\hline & & Frequency & Percent & $\begin{array}{l}\text { Valid } \\
\text { Percent }\end{array}$ & $\begin{array}{l}\text { Cumulative } \\
\text { Percent }\end{array}$ \\
\hline Valid & 1 & 1 & 4,0 & 5,6 & 5,6 \\
& 6 & 1 & 4,0 & 5,6 & 11,1 \\
& 7 & 1 & 4,0 & 5,6 & 16,7 \\
& 8 & 2 & 8,0 & 11,1 & 27,8 \\
& 9 & 3 & 12,0 & 16,7 & 44,4 \\
& 10 & 4 & 16,0 & 22,2 & 66,7 \\
& 11 & 4 & 16,0 & 22,2 & 88,9 \\
& 12 & 2 & 8,0 & 11,1 & 100,0 \\
Missing & Sotal & 18 & 72,0 & 100,0 & \\
Total & System & 7 & 28,0 & & \\
\hline
\end{tabular}

Two respondents used only "yes" choices throughout the inquiry, no one - only with "no" choices. There is only one respondent, who gave only one positive response. Most have 10 or 11 positive responses from a total of 14 possible ones.

Table 20. Descriptive Statistics.

\begin{tabular}{llllll}
\hline & N & Minimum & Maximum & Mean & $\begin{array}{l}\text { Std. } \\
\text { Deviation }\end{array}$ \\
\hline E & 20 & 1 & 7 & 4,30 & 1,525 \\
L & 20 & 0 & 7 & 4,75 & 1,888 \\
EL & 18 & 1 & 12 & 9,17 & 2,618 \\
Valid N (listwise) & 18 & & & & \\
\hline
\end{tabular}

It becomes noticeable that in both groups the positive responses are dominant, but in the second group there are more positive responses. It is observed also a bigger distraction in the answers in the second group.

The cluster analysis for both groups is applied. Using the correlation analysis it could be concluded that generally there is very little connection between the assertions in each group, i.e. the assertions are almost independent. The following analysis shows the proximity of the assertions depending on 
the answers of respondents.

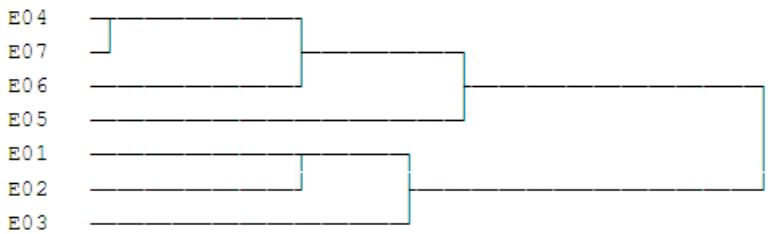

Figure 1. Hierarchical Cluster Analysis (First group's Dendrogram).

The closest are the fourth and seventh assertions and these assertions form a cluster. It is noticeable proximity between the first and second assertions at a higher level, and also between the sixth assertion and the cluster of the fourth and seventh assertions, etc. Finally two clusters are formed. The first is between the first, second and third assertions and the other is between the rest ones.

Similar results are observed from the cluster analysis. It could be remarked biggest correlation between variables E04 and E07 and between variables E06 and E07, respectively equal to 0.612 and 0.524 . Weak correlations between variables belonging to different clusters are observed.

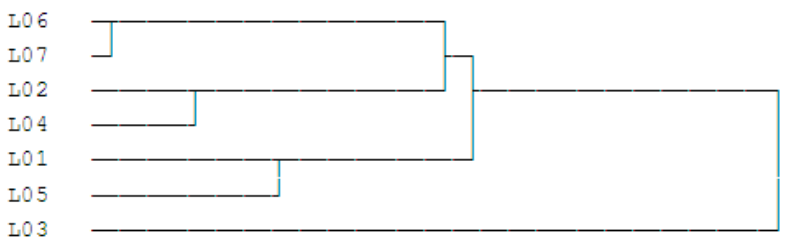

Figure 2. Hierarchical Cluster Analysis (Second group’s Dendrogram).

For the second group the dendrogram seems otherwise. There is the greatest proximity between the sixth and seventh assertions, then between second and fourth ones, followed by the proximity between the first and fifth assertions, etc. It is observed in this group consistent extension of proximity between assertions. A clear division into two or three clusters is missing.

The highest correlation is between variables L02 and L04, between variables L06 and L07, respectively equal to 0.636 and 0.596 . The variables separate two clusters with two items each and they are joined by others.

This correlation and cluster analysis can be applied also if a reformulation of the assertions in the questionnaire with a predetermined goal (for example biggest independence between assertions) is done.

\section{Conclusion}

The authors believe that one possible direction in the research process on efficacy and learning is the existence of a larger independence in assertions from each group. It is obvious that the efficiency and learning in an organizational context are interrelated and depend on the synergy of the management, but it could be concluded that the specific dimensions in the definition of concepts and statements will allow thoroughgoing relationships between units in different groups to be explored.

\section{References}

[1] Guzik, E. E. \& K. Goff (2015). The Microfoundations of Creativity: An Economics Perspective. KIE Handbook of Creativity Research Papers on Knowledge, Innovation and Enterprise, Volume III, pp. 26-27.

[2] Beghetto, R. A\& J. C. Kaufman (2007). Toward a Broader Conception of Creativity: A Case for "mini-c" Creativity. Psychology of Aesthetics, Creativity, and the Arts, Vol. 1, No. 2: 73-79.

[3] Popova, D. (2011). The Entrepreneurial Network as a Crisis Management of Human Capital, Scientific Almanac of VSU, Series "Economics and Business Administration", Issue 8, pp.162-171.

[4] Mishra, P., D. Henriksen \& the Deep-Play Research Group, Michigan State University (2013). A NEW Approach to Defining and Measuring Creativity: Rethinking Technology \& Creativity in the $21^{\text {st }}$ Century. TechTrends September/October 2013, Volume 57, Number 5.

[5] Berber, A., M. Yaslioglu (2014). Managing High Performance Work Systems and Organizational Performance. Work Organization and Human Resource Management, Springer International Publishing Switzerland, p.27.

[6] Consiglio, C., L. Borgogni, C. Di Tecco \& W. B. Schaufeli (2016). What makes employees engaged with their work? The role of self-efficacy and employee's perceptions of social context over time. Career Development International, Vol. 21, No. 2, pp. 125-143.

[7] Lisak, A., M. Erez (2015). Leadership emergence in multicultural teams: The power of global characteristics. Journal of World Business, Issue 50, pp. 3-14.

[8] Cascio, W., J. Boudreau (2016). The search for global competence: From international HR to talent management. Journal of World Business, Issue 51, pp. 103-114.

[9] Accessed: 15.06.2017 http://www.lpts.edu/about/ourleadership/president/thinking-out-loud/thinking-outloud/2014/05/27/the-mirror-test.

[10] Sull, D., Ch. Spinosa (2007). Promise - Based Management: The Essence of Execution. Harvard Business Review, pp. 7986.

[11] Bounfour, A., G. Grefe (2014). Organizational Design for Knowledge Exchange: The Hau-Ba Model. In: Learning Organizations. Extending the Field. Springer Science+Business Media Dordrecht, pp. 29-30.

[12] Edmondson, A. (2008). The Competitive Imperative of Learning, Harvard Business Review, July-August, p. 63. 